\title{
LEITURA DOS TEXTOS HISTÓRICOS EM SALA DE AULA
}

\author{
READING TEXTS OF HISTORY IN THE CLASSROOM
}

Luisa Teixeira Andrade ${ }^{1}$

\begin{abstract}
RESUMO: Esse artigo apresenta um estudo de uma aula de História acerca da temática da Antiguidade Indiana, extraída do banco de dados gerado pela pesquisa de doutorado, defendida em setembro de 2013, intitulada "Práticas de leitura em aulas de História: um estudo de caso etnográfico", que buscou investigar como a leitura dos textos de História foi socialmente construída em uma sala de aula de História da $5^{\mathrm{a}}$ série $/ 6^{\circ}$ ano do ensino fundamental da Escola Municipal Eleonora Piurucetti da Rede pública de ensino de Belo Horizonte. Os princípios teóricos e metodológicos de análise se basearam em uma tendência contemporânea de análise das interações em sala de aula: a Etnografia Interacional. Nessa perspectiva, buscamos compreender como a leitura dos textos de História foi discursivamente construída pelos membros por meio de suas interações, verbais ou não verbais, e como essas construções influenciaram as oportunidades disponíveis aos estudantes de ler e aprender História na sala de aula observada.
\end{abstract}

Palavras-chave: Ensino-aprendizagem de História. Sala de aula. Leitura.

\begin{abstract}
This article presents a study of a history lesson on the theme of ancient Indian, extracted from the database generated by the doctoral research, held in September 2013, titled "Reading practices in history classes: a case study ethnographic "which sought to investigate how reading the history texts was socially constructed in a history classroom of 5th grade / 6th grade of elementary school of the Municipal School Piurucetti Eleonora of Belo Horizonte teaching public network. The theoretical and methodological principles of analysis were based on a contemporary trend analysis of the interactions in the classroom: the Interactional Ethnography. From this perspective, we seek to understand how to read the history texts was discursively constructed by the members through their interactions, verbal or non-verbal, and how these constructions influence the opportunities available to students to read and learn history in the classroom observed.
\end{abstract}

Keywords: Teaching and learning history. Classroom. Reading.

1 É mestre e doutora em Educação pela FaE/UFMG e fez doutorado-sanduiche na University of California, Santa Barbara/USA no departamento de Educação. Professora do Departamento de História e Pedagogia do Centro Universitário de Belo Horizonte - UNIBH. Pesquisadora do Laboratório de Estudos e Pesquisas em Ensino de História (Labepeh) da UFMG. 
"Quando a gente tá fazendo a leitura de um texto, qualquer texto, é muito importante a gente ler para além das palavras, do que que a palavra tá escrita, no concreto, mas o que que é, qual é o sentido daquela palavra, qual é o sentido daquela frase. Quando a gente passa a tomar cuidado com a leitura é, pra gente perceber o que está nas entrelinhas, ou o que que tá sendo dito, também, naquelas palavras, a gente acaba, aprendendo, acaba aprendendo melhor, compreendendo mais facilmente o sentido das coisas, tá bom?" Professor Odilon

\section{Introdução}

O que tem sido, para os alunos, o ato de ler a escrita escolar da história quando mediados pelo professor em salas de aula? Aisenberg, em seu artigo " Uma aproximación a la relación entre la lectura y el aprendizaje de la história" (2005), lança aos professores de História uma provocação: eles não ensinam seus alunos a lerem os textos, eles simplesmente utilizam os textos para que seus alunos localizem informações. Aisenberg, concordando com Lautier (1997) diz que estes usos dos textos correspondem a um modelo de ensino de História que dissocia o ato de ler em duas fases temporais: primeiro a incorporação da informação e, depois, a interpretação e a explicação. E avança o seu raciocínio dizendo que a leitura não é considerada como um trabalho inerente à construção do conhecimento histórico, somente oferece vestígios para ele e que quem assim concebe a leitura considera que o sentido do texto já está dado. Portanto, nessas situações, o texto encontra-se fora do leitor cabendo a ele, apenas, extrair dos textos as informações nele contidas. Em contraposição a essa concepção Aisenberg defende:

Ler é construir significado na interpretação do texto. Construir o significado de um texto de História supõe empregar raciocínios compatíveis com algumas operações necessárias para a construção do conhecimento histórico: criar e recriar representações sobre os eixos, relaciona-los e explicar como estão conectados em uma trama consistente que dê conta dos "por quês" dos eixos e da intencionalidade dos sujeitos, reorganizar 0 conhecimento anterior incorporando conhecimento novo. Em fim, em certas condições, ler História é aprender História (AISENBERG, 2012, p. 270). 
Esta perspectiva defendida por Aisemberg nos sugere buscar outros elementos que venham contribuir para a construção de uma perspectiva teórico metodológica com vistas a orientar investigações e ações docente no campo das práticas de leitura em História. Nesse sentido, assumimos uma premissa. Existe uma diversidade de práticas de leitura a ser conhecida, uma vez que os leitores professores e alunos - são diversos e lêem em condições singulares e diversas (BATISTA, 2001; ESPÍNDOLA, 2003; ANDRADE 2006, SIMAN E ANDRADE, 2008; COELHO 2009, CARIE 2003; ROCHA, 2009).

Respondendo a essa premissa, esse texto apresenta um estudo de uma aula de História acerca da temática da Antiguidade Indiana, extraída do banco de dados gerado pela pesquisa de doutorado, defendida em setembro de 2013, intitulada "Práticas de leitura em aulas de História: um estudo de caso etnográfico"2, que buscou investigar como a leitura dos textos de História foi socialmente construída em uma sala de aula de História da $5^{\mathrm{a}}$ série $/ 6^{\circ}$ ano do ensino fundamental da Escola Municipal Eleonora Piurucetti da Rede pública de ensino de Belo Horizonte. Os princípios teóricos e metodológicos de análise se basearam em uma tendência contemporânea de análise das interações em sala de aula: a Etnografia Interacional. Essa abordagem é informada pelo entendimento do papel central do discurso nos processos de construção de conhecimentos em salas de aula (BLOOME AND BAILEY, 1992; BLOOME AND EGAN-ROBERTSON, 1993; COLLINS AND GREEN, 1992; GEE AND GREEN, 1998; SANTA BARBARA CLASSROOM DISCOURSE GROUP, 1992). Nessa perspectiva, buscamos compreender como a leitura dos textos de História foi discursivamente construída pelos membros por meio de suas interações, verbais ou não verbais, e como essas construções influenciaram as oportunidades disponíveis aos estudantes de ler e aprender História na sala de aula observada. Os procedimentos metodológicos incluíram registros em vídeo; notas de campo; materiais coletados durante a observação participante - quais sejam, cadernos de alunos, textos e testes -; análise do espaço institucional; entrevistas com o professor e nove alunos; e um tempo prolongado de imersão em campo - oito meses. Desse modo, acompanhamos, sob

\footnotetext{
2 Esta tese de doutorado contou com a orientação da professora Maria Lúcia Castanheira FaE/UFMG, Júnia Sales Pereira FaE/UFMG (co-orientadora) e Judith L. Green University of California, Santa Barbara (orientadora estrangeira em ocasião do doutorado-sanduiche desenvolvido na University of California, Santa Barbara, durante o ano de 2012)
} 
o viés etnográfico, a sala de aula de História pesquisada, observando o cotidiano da classe.

\section{Uma sala onde se ensina a ler para aprender História}

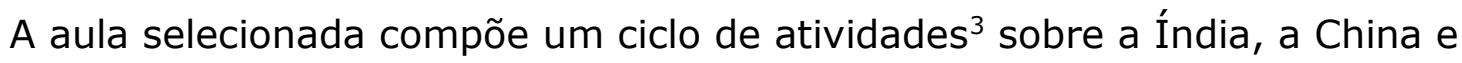
o Japão antigos que compreendeu onze aulas no total. Nesse ciclo de atividades, o professor explorou o capítulo do livro didático ${ }^{4}$ sobre o tema de forma integral e lançou mão de variadas "maneiras de ler" e "tipos de textos" com propósitos variados, em situações variadas. A prática de "leitura debatida", objeto dessa análise, foi a principal atividade do ciclo, presente em quatro aulas. A aula selecionada para essa análise teve como enfoque a Leitura oral e discussão de uma revista e "Leitura debatida" do texto do livro didático. A partir da análise da forma como os participantes construíram coletivamente os limites dos eventos, identificamos nesta aula quatro deles: "Acomodando-se nas carteiras e conversando entre si"; "Organizando a dinâmica de leitura" (analisado acima); "Lendo e discutindo a revista de divulgação científica" e "Lendo o livro didático de História". No evento "Lendo o livro didático de História" os alunos engajaram-se na leitura coletiva e discussão das primeiras páginas do capítulo que versavam sobre a Índia na antiguidade. As pistas contextuais, as fases de atividade e os temas permitiram-nos recortar esse evento em seis subeventos, quais sejam, "Discutindo a representação da deusa-mãe"; "lendo sobre as manifestações religiosas dos árias"; "Lendo sobre o bramanismo e discutindo"; "Discutindo as características da estatueta da deusa-mãe"; "Lendo sobre o hinduísmo e discutindo"; "Lendo sobre o budismo e discutindo". Analisaremos aqui o subevento "Discutindo a representação da deusa-mãe", buscando compreender como a leitura dos textos de História foi sendo construída nesta classe e quais narrativas históricas emergiram nas interações através de formas de ler específicas da História.

${ }^{3}$ Chamado aqui de "ciclo de atividades", um circuito completo de atividades comporta uma série de eventos tematicamente interligados, no caso desta pesquisa, uma lição completa de um capítulo do livro didático utilizado.

${ }^{4}$ O livro didático adotado intitule-se História: das cavernas ao terceiro milênio, de Patrícia Ramos Braick e Myriam Becho Mota, Editora Moderna. 


\subsection{Analisando o subevento "Discutindo a representação da deusa-mãe"}

A análise do subevento teve duas lentes: a primeira focou a forma como a prática de leitura foi socialmente construída pelos participantes: quem leu, de que forma, com quais objetivos, com quais resultados, sob quais condições. A segunda lente focalizou as (re)construções do texto/narrativas históricas produzidas nas interações sociais. Essas lentes nos permitiram entender como o professor foi construindo modos particulares de ler e aprender História nesta sala de aula.

Para analisar o evento "Discutindo a representação da deusa-mãe" optamos por fazer uma "revelação progressiva" dos dados. Nesse sentido, recortamos, para fins de análise, o primeiro subevento em três sequências interacionais, quais sejam, "Lendo oralmente o subitem 'As primeiras manifestações religiosas" "; "Discutindo as entrelinhas da representação da deusa-mãe"; "Imaginando a estatueta da deusa-mãe". Com isso, o leitor acompanhará mais de perto a análise dos dados.

Segue abaixo, portanto, a transcrição e análise da primeira sequência interacional "Lendo oralmente o subitem 'As primeiras manifestações religiosas' ", do subevento "Discutindo a representação da deusa-mãe". Os nomes dos alunos são fictícios por motivo de sigilo de identidade dos sujeitos pesquisados e os aspectos extralingüísticos e/ou pistas contextuais (Gumperz. 1992), quais sejam, pausas, expressões, gestos e outros; os comentários da pesquisadora ocupam uma coluna separada. Não utilizamos nenhuma correção no texto produzido oralmente.

\begin{tabular}{|c|c|c|}
\hline $\mathbf{P}$ & Discurso & Aspectos Culturais \\
\hline \multirow[t]{3}{*}{$P$} & $\begin{array}{l}\text { [Assenta na carteira - estava em pé } \\
\text { discutindo o assunto anterior com a } \\
\text { turma] }\end{array}$ & $\begin{array}{l}\text { Mudança de espaço } \\
\text { interacional }\end{array}$ \\
\hline & $\begin{array}{l}\text { Vamos lá/ gente/ continuando/ [Alunos } \\
\text { falam ao mesmo tempo] } \\
\text { Tá/ vamos lá?/ Vamos voltar aqui o } \\
\text { assunto?/ Então vamos lá/ }\end{array}$ & $\begin{array}{l}\text { Direcionando para } \\
\text { uma nova atividade, } \\
\text { nova sequência. }\end{array}$ \\
\hline & $\begin{array}{l}\text { [professor folheia o livro enquanto os } \\
\text { alunos conversam]Página... }\end{array}$ & $\begin{array}{l}\text { Localizando a parte a } \\
\text { ser lida. }\end{array}$ \\
\hline Als & $120 !$ & $\begin{array}{l}\text { Direcionando a parte a } \\
\text { ser lida }\end{array}$ \\
\hline$P$ & $\begin{array}{l}\text { Não/ não/ essa parte a gente tinha } \\
\text { acabado de ler/ aí eu lembrei da revista } \\
\text { que estava fazendo comentário sobre as }\end{array}$ & $\begin{array}{ll}\text { Retomando } & \mathrm{o} \\
\text { direcionamento } & \mathrm{e}\end{array}$ \\
\hline
\end{tabular}




\begin{tabular}{|c|c|c|}
\hline & $\begin{array}{l}\text { castas/ É na cento e vinte.../ e um/ Tá?/ } \\
\text { "As primeiras manifestações religiosas"/ }\end{array}$ & $\begin{array}{l}\text { indicando a parte a ser } \\
\text { lida. }\end{array}$ \\
\hline & $\begin{array}{l}\text { Leia para mim.../[verificando sua lista de } \\
\text { chamada]/ Laís!/ }\end{array}$ & $\begin{array}{l}\text { [Alguns levantam a } \\
\text { mão] }\end{array}$ \\
\hline Laís & $\begin{array}{l}\text { Pouco se sabe sobre as crenças dos } \\
\text { harapenses/ A partir do estudo de/ } \\
\text { objetos encontrados nas ruínas/ de } \\
\text { Harapa/ e de Monhenjo/ Daro/ os arque/ } \\
\text { ólogos/ concluíram que adoravam/ a } \\
\text { deusa-mãe/ representada com seios } \\
\text { grandes/ e quadris largos/ Também } \\
\text { foram achadas/ peças adornadas/ com } \\
\text { figuras de unicórnios/ cavalos com um } \\
\text { chifre único no meio da testa/ e de } \\
\text { minotauros/ homens com cabeça de } \\
\text { touro/, seres mitológicos que/ } \\
\text { aparentemente eram/ cultuados/ pela } \\
\text { população/ } \\
\text { Veja a figura 8/ }\end{array}$ & $\begin{array}{l}\text { [lêr primeiro } \\
\text { parágrafo] } \\
\text { Alunos focando o livro, } \\
\text { indicando ao professor } \\
\text { seguir a leitura. } \\
\text { Poucos alunos } \\
\text { dispersos. } \\
\text { Aluna faz uma pausa a } \\
\text { partir da indicação do } \\
\text { texto da leitura de } \\
\text { outro tipo de texto: a } \\
\text { legenda. }\end{array}$ \\
\hline$P$ & $\begin{array}{l}\text { A figura 8/ lê do lado aí pra mim a } \\
\text { legenda/ }\end{array}$ & \\
\hline Laís & $\begin{array}{l}\text { Selo de pedra com a figura/ do unicórnio/ } \\
\text { Os pesquisadores acreditam que/ os } \\
\text { mercadores/ harapenses/ usavam essas } \\
\text { peças para identificar seus produtos/ }\end{array}$ & $\begin{array}{l}\text { [lê a legenda] A aluna } \\
\text { faz uma pausa na } \\
\text { leitura após o término } \\
\text { da leitura da legenda e } \\
\text { olha para o professor. } \\
\text { Parece indicar que } \\
\text { aguarda novo } \\
\text { direcionamento. }\end{array}$ \\
\hline $\mathrm{P}$ & $\begin{array}{l}\text { tá/nesse texto que a .../ que a .../Laís/ } \\
\text { acabou de ler falou da deusa-mãe/ né?/ } \\
\text { Por que vocês acham que a deusa-mãe/ } \\
\text { foi representada/ com seios grandes/ e } \\
\text { quadris largos?/ }\end{array}$ & $\begin{array}{l}\text { Selecionando uma } \\
\text { parte do texto lido: a } \\
\text { representação da } \\
\text { deusa-mãe. } \\
\text { Propondo aos alunos a } \\
\text { leitura de uma } \\
\text { representação de uma } \\
\text { deusa da antiguidade } \\
\text { Indiana. } \\
\text { Definindo os alunos } \\
\text { como leitores de uma } \\
\text { fonte histórica. }\end{array}$ \\
\hline
\end{tabular}

Tabela 1: Representação da sequência "Lendo oralmente o subitem 'As primeiras manifestações religiosas' " do subevento "Discutindo a representação da deusa-mãe" - Aula de 10/09/2010

O início do subevento acima é marcado pelo processo de passagem para o subevento subsequente, Paulatinamente, os alunos foram lendo as pistas 
contextuais e construindo um novo contexto interacional, uma nova atividade e um novo tema: um novo evento. Essa transição foi observada, em primeiro lugar, pela mudança de espaço interacional do professor, ele alternou entre interagir com a turma de pé no centro da sala e interagir com a turma assentado em sua mesa folheando o livro didático. Em segundo lugar, em conjunto com a mudança de espaço interacional, o professor promoveu o início da atividade com o livro didático, indicando a parte a ser lida e escolhendo uma aluna para ler a partir da consulta de sua lista de presença. Segundo as notas de campo, o professor registrava na lista de chamada os alunos que já haviam lido para que os leitores se alternassem. Isso significou a passagem de uma atividade em que ele trabalhava a leitura e discussão de um texto de uma revista de divulgação científica ${ }^{5}$ para outra com foco na leitura e discussão do texto do capítulo do livro didático sobre a Índia, China e Japão antigos.

Essas pistas contextuais indicaram o fechamento e a abertura de uma nova sequência de atividades que se iniciou com a leitura, pela aluna Laís, do subtítulo do livro didático "As primeiras manifestações religiosas". (vide imagem abaixo)

\section{As primeiras manifestações religiosas}

Pouco se sabe sobre as crenças dos harapenses. A partir do estudo de objetos encontrados nas ruínas de $\mathrm{Ha}$ rapa e de Mohenjo Daro, os arqueólogos concluíram que adoravam a deusa-mãe, representada com seios grandes e quadris largos. Também foram achadas peças adornadas com figuras de unicórnios (cavalos com um chifre único no meio da testa) e de minotauros (homens com cabeça de touro), seres mitológicos que aparentemente eram cultuados pela população. Veja a figura 8 .

Quanto aos árias, suas manifestações religiosas mais antigas envolviam o culto às forças da natureza (tempestades, ventos etc.) e aos deuses que as representavam. Para agradar aos deuses, faziam oferendas de ouro ou de bebidas e sacrificavam animais.

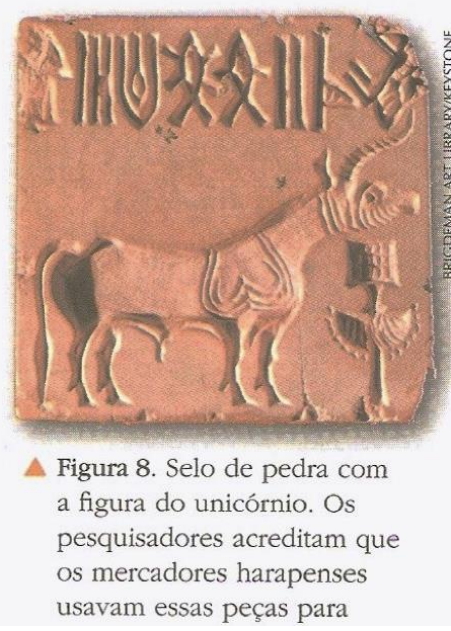

Figura 1: Excerto lido do livro didático da p. 121

\footnotetext{
${ }^{5}$ Revista "Superinteressante", 2001.
} 


\begin{tabular}{|c|c|c|}
\hline $\mathbf{P}$ & Discurso & $\begin{array}{l}\text { Aspectos } \\
\text { Culturais }\end{array}$ \\
\hline$P$ & $\begin{array}{l}\text { tá/nesse texto que a .../ que a .../Laís/ } \\
\text { acabou de ler falou da deusa-mãe/ né?/ Por } \\
\text { que vocês acham que a deusa-mãe/ foi } \\
\text { representada/ com seios grandes/ e quadris } \\
\text { largos?/ } \\
\text { [Propondo aos alunos a leitura de uma } \\
\text { representação de uma deusa da antiguidade } \\
\text { Indiana.] }\end{array}$ & $\begin{array}{l}\text { Selecionando uma } \\
\text { parte do texto } \\
\text { lido: ra } \\
\text { representação da } \\
\text { deusa- } \\
\text { mãe.Definindo os } \\
\text { alunos como } \\
\text { leitores de uma } \\
\text { fonte histórica. }\end{array}$ \\
\hline Ru & Por causa que ela era mais bonita/ & $\begin{array}{l}\text { Sugerindo que os } \\
\text { seios grandes e } \\
\text { quadris sejam } \\
\text { sinais de beleza. }\end{array}$ \\
\hline Lor & A mais poderosa?/ & $\begin{array}{l}\text { Associando a ideia } \\
\text { de poder. }\end{array}$ \\
\hline$P$ & $\begin{array}{l}\text { Pera aí/ o Ruan tá achando que tá } \\
\text { relacionado à beleza/ descrição de beleza/ A } \\
\text { Lorena/ tá achando que tá relacionado a } \\
\text { poder/ Lucas/ [Organizando as ideias dos } \\
\text { alunos] }\end{array}$ & $\begin{array}{l}\text { Reforçando o } \\
\text { papel dos alunos } \\
\text { de leitores da } \\
\text { representação. }\end{array}$ \\
\hline LuC & $\begin{array}{l}\text { Professor/ eu acho que é entre os dois/ por } \\
\text { que?/ um/ ela tinha que ser mais bonita que } \\
\text { todo mundo/ que todas as outras } \\
\text { mulheres.../ }\end{array}$ & $\begin{array}{l}\text { Relacionando as } \\
\text { ideias dos colegas. }\end{array}$ \\
\hline$P$ & $\begin{array}{l}\text { a deusa-mãe?/ É importante que a deusa/ } \\
\text { mãe seja a mais bonita?/ }\end{array}$ & $\begin{array}{l}\text { Questionando a } \\
\text { ideia da beleza. }\end{array}$ \\
\hline Lor & é mais poderosa & $\begin{array}{l}\text { Reiterando sua } \\
\text { ideia. }\end{array}$ \\
\hline LuC & $\begin{array}{l}\text { Não/ porque todos pensavam que ela 'seja' } \\
\text { mais bonita que todas as mulheres/ e } \\
\text { segunda coisa/ mais ponderosa/ mais } \\
\text { poderosa porque ela era/ porque ela era/ a } \\
\text { deusa mãe/ }\end{array}$ & \begin{tabular}{ll}
\multicolumn{2}{l}{ Desconsiderando } \\
a fala professor ao \\
concluir \\
comentário \\
associa as \\
dos colegas. \\
\end{tabular} \\
\hline Will & $\begin{array}{l}\text { Fessor?/é.../ assim/ tipo que eles 'achava'/ } \\
\text { tipo/ eles viram uma mulher/ aí como eles } \\
\text { falavam deusa mãe/ era mulher/ aí eles } \\
\text { consideravam uma mulher/ Eles } \\
\text { representavam/ }\end{array}$ & $\begin{array}{l}\text { Associando seios } \\
\text { grandes a quadric } \\
\text { largos a } \\
\text { característica de } \\
\text { ser mulher. }\end{array}$ \\
\hline$P$ & $\begin{array}{l}\text { Mas por que que você acha/ que eles } \\
\text { representavam?/ Gente/ vamos lá/ vamo.../ } \\
\text { Eu acabei de.../ gente!/ [estala os dedos] } \\
\text { Eu acabei de discutir com vocês a }\end{array}$ & $\begin{array}{l}\text { Questionando a } \\
\text { fala do aluno. } \\
\text { Assegurando que } \\
\text { o que ele quer }\end{array}$ \\
\hline
\end{tabular}




\begin{tabular}{|c|c|c|}
\hline & $\begin{array}{l}\text { importância da gente ler nas entrelinhas/ } \\
\text { Da gente ler o que que tá por trás da } \\
\text { mensagem/ Tá?/ Então vamos prestar } \\
\text { atenção/ por que que a deusa mãe/ tem } \\
\text { seios grandes e quadris largos/ O que que } \\
\text { torna uma mulher mãe }\end{array}$ & $\begin{array}{ll}\text { discutir são } & \text { os } \\
\text { motivos } & \text { da } \\
\text { representação. } & \end{array}$ \\
\hline Fel & $\begin{array}{l}\text { [interrompendo o professor]: Acho que ela } \\
\text { pode amamentar os filhos/ }\end{array}$ & $\begin{array}{l}\text { Explicitando que a } \\
\text { amamentação que } \\
\text { faria de uma } \\
\text { mulher mãe. }\end{array}$ \\
\hline$P$ & $\begin{array}{l}\text { Isso!/ Felipe/ era isso que eu queria ouvir!/ } \\
\text { [Alunos batem palmas] } \\
\text { O que que torna uma mulher.../ gente!!!!/ o } \\
\text { que que torna uma mulher mãe?/ }\end{array}$ & $\begin{array}{l}\text { Elogiando a fala do } \\
\text { Fel., dizendo que } \\
\text { supriu suas } \\
\text { expectativas. }\end{array}$ \\
\hline Will & Fazer sexo/ [alunos começam a rir] & $\begin{array}{l}\text { [alunos rindo e } \\
\text { conversando] }\end{array}$ \\
\hline$P$ & $\begin{array}{l}\text { Fazer sexo não torna uma mulher mãe/ Não } \\
\text { necessariamente!!!/ A mulher pode fazer } \\
\text { sexo e não engravidar e não se tornar } \\
\text { mãe!/Olha só/ a minha pergunta.../Presta } \\
\text { atenção na pergunta que eu tô } \\
\text { fazendo/Vocês estão muito preocupados em } \\
\text { dar respostas difíceis e elaboradas.../[Alunos } \\
\text { rindo] }\end{array}$ & 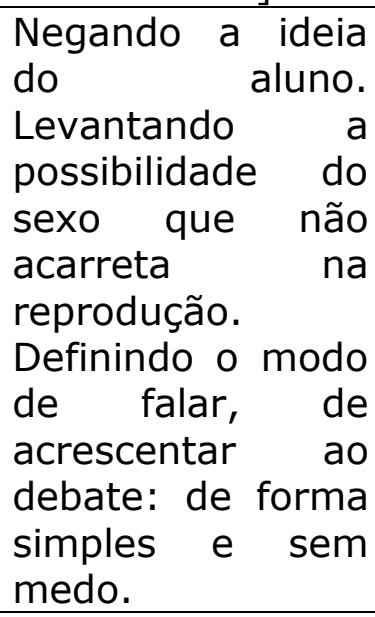 \\
\hline$P$ & $\begin{array}{l}\text { Gente, olha só/ Natali!/ Posso continuar } \\
\text { aqui?/ Bom/ [bebe água]/ Isso que o Felipe } \\
\text { acabou de fazer/ e mesmo o que o William } \\
\text { acabou de fazer/ embora ele tenha/ ele } \\
\text { tenha brincado com a ideia de sexo ai/ Só } \\
\text { um minutinho [para Ruan, encostando a } \\
\text { mão nele]/ } \\
\text { Eu tô precisando.../ Eu tô precisando que } \\
\text { vocês falem um pouco mais sem medo!/ } \\
\text { Porque eu tô perguntando as coisas/ e todo } \\
\text { mundo fica querendo dar uma resposta } \\
\text { muito difícil/ e complicada./ Então quando } \\
\text { eu perguntei/ o que que faz/ de uma mulher/ } \\
\text { ser mãe/ o que que faz uma mulher mãe? }\end{array}$ & $\begin{array}{l}\text { [Chama atenção } \\
\text { de alguns alunos } \\
\text { enquanto explica] } \\
\text { Fazendo uma } \\
\text { pergunta e } \\
\text { respondendo-a. } \\
\text { Certificando se a } \\
\text { turma está } \\
\text { acompanhando. } \\
\text { Reforçando a } \\
\text { assertiva por meio } \\
\text { da repetição. } \\
\text { Tentando formular } \\
\text { sua explicacão a } \\
\text { partir da voz do } \\
\text { aluno Felipe. }\end{array}$ \\
\hline Fel & $\begin{array}{l}\text { Amamentar os seus filhos![Paiva pede para } \\
\text { falar] }\end{array}$ & $\begin{array}{l}\text { Preenchendo a } \\
\text { lacuna }\end{array}$ \\
\hline
\end{tabular}




\begin{tabular}{|c|c|c|}
\hline$P$ & $\begin{array}{l}\text { Amamentar seus filhos/ Não é?/ Alimentar/ } \\
\text { senão ele não vai .../ sobreviver/ Não é?/ } \\
\text { Então.../ quando.../ Paiva/ só um minutinho/ } \\
\text { eu já vi que você quer falar/ Quando o } \\
\text { homem láaaa/ na Antiguidade/ quis } \\
\text { representar a deusa- mãe/ qual foi a } \\
\text { preocupação/ dele/ em retratá-la?/O que } \\
\text { que ele pensou em agregar à imagem dessa } \\
\text { deusa mãe/ para ela simbolizar/ só da gente } \\
\text { bate o / e saber que ela era uma deusa/ a } \\
\text { deusa mãe/ }\end{array}$ & $\begin{array}{lr}\text { Reformulando } & \text { a } \\
\text { pergunta, } & \\
\text { incluindo } & \text { o } \\
\text { homem } & \text { da } \\
\text { antiguidade, as } \\
\text { intenções } \\
\text { preocupacões que } \\
\text { tinha em mente ao } \\
\text { representar a } \\
\text { deusa-mãe. }\end{array}$ \\
\hline $\mathrm{Ru}$ & $\begin{array}{l}\text { eu/ 'fessor'!/ Pra fazer os seios grandes/ e } \\
\text { os quadris também/ grandes!/ }\end{array}$ & $\begin{array}{ll}\text { Definindo } & a \\
\text { representação. } & \end{array}$ \\
\hline$P$ & $\begin{array}{l}\text { por quê/ o que que isso significa/ seios } \\
\text { grandes/ e quadris largos?/ gesticulando } \\
\text { com o dedo apontando para Ruan e gesticula } \\
\text { com o braço que Paiva pode falar] }\end{array}$ & $\begin{array}{ll}\text { Pedindo } & \text { os } \\
\text { motivos, } & \text { os } \\
\text { significados de tal } \\
\text { representação. }\end{array}$ \\
\hline Gab & $\begin{array}{l}\text { Por causa/ que o quadril tava largo porque } \\
\text { ela tava/ grávida/ e os seios grandes/ } \\
\text { porque ela ia amamentar/ }\end{array}$ & $\begin{array}{l}\text { Trazendo os } \\
\text { motivos da } \\
\text { representação: } \\
\text { quadris largos } \\
\text { porque ela estava } \\
\text { grávida e seios } \\
\text { grandes porque } \\
\text { ela ia amamentar. }\end{array}$ \\
\hline$P$ & $\begin{array}{l}\text { tá/ agora vem a pergunta/ [segurando a } \\
\text { revista] Todos vocês aqui/ já conseguiram } \\
\text { imaginar a estátua/ da deusa-mãe?/ }\end{array}$ & $\begin{array}{l}\text { Mudando o foco da } \\
\text { atividade. } \\
\text { Encorajando os } \\
\text { alunos a imaginar } \\
\text { a estátua da } \\
\text { deusa-mãe. }\end{array}$ \\
\hline
\end{tabular}

Tabela 2: Representação da transcrição da sequência "Discutindo as entrelinhas da representação da deusa-mãe" do subevento "Discutindo a representação da deusa-mãe" - Aula de 10/09/2010

Acima, continuamos a transcrição da sequência "Discutindo as entrelinhas da representação da deusa-mãe" do mesmo subevento, buscando analisar a forma como o professor e os alunos (re)construíram e (re)significaram o trecho lido oralmente.

Prosseguindo a análise da segunda sequência do subevento, podemos observar que o professor alterou a atividade de ler para a de discutir a leitura sobre uma parte específica do texto lido: a representação de uma deusa indiana da antiguidade. A intervenção do professor "Por que vocês acham que a deusamãe/ foi representada/ com seios grandes/ e quadris largos?/" trouxe à tona alguns elementos para a análise. Ao propor aos alunos a "leitura" de uma 
representação de uma deusa indiana da antiguidade, o professor convocou a turma a fazer um exercício próprio da disciplina História e dos historiadores, qual seja, ler e interpretar fontes históricas. Ele conferiu aos alunos o papel de leitores/debatedores de uma fonte histórica. Mais ainda, ele convidou os alunos a ler a fonte em sua complexidade, ler suas entrelinhas, suas metáforas, seus não ditos, seus simbolismos. A imagem da deusa-mãe representa um objeto da cultura material portador de informações sobre costumes, técnicas, condições econômicas, ritos e crenças da antiguidade indiana. Ao fazer com os alunos um esforço de leitura do documento histórico, o professor possibilitou um contato mais concreto deles com a História dos antepassados indianos, trazendo para o presente dos alunos realidades ausentes através dos vestígios que persistiram à revelia do tempo.

No entanto, o documento não fala senão quando interrogado. É necessário fazer-Ihe perguntas relevantes susceptíveis de agregar uma multiplicidade de sentidos a ele. Os significados de uma fonte histórica, como qualquer outro "texto", não estão nela mesma, uma vez que são construídos através de um processo de interação social. Desse modo, o evento de leitura co-construído por professor e alunos ao redor da representação da deusa-mãe forneceu pistas e conformou o modo como essa fonte foi lida. O modo como a fonte foi significada, portanto, dependeu da narrativa, discussão e interpretação em torno dela.

O primeiro aluno a se voluntariar para ler e interpretar os simbolismos contidos na fonte histórica foi o Ruan que sugeriu que os seios grandes e os quadris largos da deusa-mãe fossem sinais de beleza: "Por causa que ela era mais bonita/". Já Lorena associou às características físicas da deusa-mãe a ideia de poder: "a mais poderosa?/". O professor, então, estruturou o comentário dos alunos, repetindo-os, com a indicação dos autores: "Pera aí/ o Ruan tá achando que tá relacionado à beleza/ descrição de beleza/ A Lorena/ tá achando que tá relacionado a poder/". Desse modo, ele reforçou o papel dos estudantes como leitores da representação/fonte histórica.

Na continuação da aula, o aluno Lucas pediu para falar. Uma vez autorizado, ele voltou às características da deusa-mãe, numa reflexão que resgatou pontos dos comentários anteriores: "Professor/ eu acho que é entre os dois/ por quê?/ um/ ela tinha que ser mais bonita que todo mundo/ que todas as outras 
mulheres.../" O professor, porém, interrompeu-o questionando-lhe sua interpretação sobre a beleza da deusa-mãe: "A deusa-mãe?/ É importante que a deusa/ mãe seja a mais bonita?/". Lucas, então, retomou sua fala, buscando costurar uma leitura que conciliava as ideias dos colegas. Apesar do esforço, ele não respondeu ao do professor, negligenciando a questão sobre a beleza: "Não/ porque todos pensavam que ela 'seja' mais bonita que todas as mulheres/ e segunda coisa/ mais poderosa/ mais poderosa porque ela era/ porque ela era/ a deusa-mãe/".

Pode ser que os alunos Ruan e Lucas estiveram influenciados pela força semântica da palavra "deusa", pois logo fizeram referência a beleza da deusamãe. Na linguagem coloquial encontramos várias situações em que a palavra "deusa" adquire a conotação de mulher bela. Dizer que uma mulher é uma "deusa", não quer dizer outra coisa senão, que ela é muito bonita. Por outro lado, como bem observou a aluna Lorena, a mesma palavra sugere poder. Nesse caso, "deusa-mãe" significa a mais importante de todas as mães. Assim, em suas tentativas de ler a fonte histórica e entender os simbolismos da representação da deusa-mãe, os alunos fizeram associações a partir dos valores culturais de que dispunham, oriundos de suas práticas sociais, de seus grupos de pertencimento, do tempo e espaço histórico de que pertencem e de suas próprias percepções de mundo.

Essa análise nos permite evidenciar que os alunos atrelaram às características físicas da deusa-mãe, valores estéticos e sociais do universo cultural a que pertencem. Eles, então, associaram a representação da deusa-mãe de seios grandes e quadris largos, à beleza física e ao poder, características vinculadas à ideia de deusa. O contato com o texto histórico deu ensejo à produção de sentidos, construídos coletivamente e ancorados nas experiências plurais com outros textos e no conhecimento histórico. Desse modo, os conhecimentos, valores de mundo dos alunos, foram transpostos e reelaborados na leitura da fonte histórica da antiguidade indiana. Esses valores estéticos, imagens, simbolismos oriundos do universo cultural dos alunos, ao serem ativados na interpretação da representação da deusa-mãe, funcionaram como uma perspectiva referencial a partir da qual a interpretação e produção de significados foi estabelecida. 
Seguindo o fluxo, Willian teceu um comentário inaudível e, em resposta, o professor reforçou seu objetivo de discutir os motivos da representação: "Mas por que que você acha/ que eles representavam?/".

Depois disso, verificando que o esforço de leitura dos alunos estava aquém do esperado, exigiu um maior empenho de interpretação do documento por parte dos alunos. Para isso, ele chamou a atenção da turma e recuperou a discussão de enunciados anteriores (do evento anterior) sobre a importância de ler as mensagens subliminares do texto: "Gente/ vamos lá/ vamo.../ Eu acabei de discutir com vocês a importância da gente ler nas entrelinhas/ Da gente ler o que que tá por trás da mensagem". Nesse momento, o professor retomou a forma como o texto deveria ser lido, definida nas falas anteriores desta mesma aula, produzindo o que Floriani (1993) chamou de conexões intercontextuais ou intercontextualidade ${ }^{6}$. Dessa forma, o professor torna explícita para os alunos a relação entre textos/contextos relevantes para a História local e reafirma a necessidade do que haviam discutido anteriormente: a importância de se ler nas entrelinhas, de se ler o que está "por trás da mensagem".

Ora, a leitura nas entrelinhas constitui-se em exercício fundamental para o modo de pensar histórico. Um dos procedimentos da compreensão da História, já que ela, por ser conhecimento também arbitrado, institui-se por meio de escolhas. Essas escolhas, sabemos, não dão a ver a toda a história, mas a uma versão arbitrada. Ler nas entrelinhas é exercício do pensar investigativo face ao jogo e disputa ideológica entre grupos que buscam fazer prevalecer certas narrativas históricas sobre outras, ou risco de se reificar a narrativa histórica como um entidade única, imutável, e objetiva e impessoal. Parece que aqui ele suscita a percepção de que a narrativa do livro não é unívoca - há algo sob ela, para além dela... algo não dito.

No evento anterior, "Lendo e discutindo o texto da revista" (ao qual o professor se refere: "Eu acabei de discutir com vocês a importância da gente ler nas entrelinhas"), o professor leu para a classe um texto da revista de iniciação

\footnotetext{
${ }^{6}$ Segundo a perspectiva teórica da Etnografia Interacional, o processo de construção de significados pelos indivíduos da sala de aula é interdependente de símbolos/textos/contextos criados em outros espaços interacionais e relacionados a eles (CASTANHEIRA, 2000). Desse modo, determinado evento pode estar ligado a outros eventos constitutivos da História local de uma comunidade de sala de aula produzindo o que Floriani (1993) chamou de conexões intercontextuais ou intercontextualidade.
} 
científica sobre mitologia indiana que versava sobre a origem das castas. A premissa é de que as castas surgiram de um ser que "era ao mesmo tempo homem e mulher, e deu origem a várias formas de vida", e foi "responsável pela criação das castas indianas". De acordo com o texto, as castas indianas brotaram de cada uma das quatro partes de seu corpo, "da cabeça vieram os sacerdotes, os guerreiros de seus braços, os artistas, comerciantes e fazendeiros vieram de suas coxas e, por fim, os sutras, ou os trabalhadores, surgiram de seus pés". Após a leitura desse texto, o professor sugeriu que os alunos pensassem nas intenções implícitas no mito de origem das castas indianas: "que conclusão que a gente pode tirar/ da origem da casta dos sacerdotes/ e da origem da parte do corpo que originou a casta dos trabalhadores/". Os alunos foram levados a fazer uma leitura das entrelinhas do texto, de suas metáforas, de suas analogias, de seus não ditos. No final do debate aflorado pela ancoragem do professor, ele fez uma síntese conscientizando os alunos da importância de se ler o texto buscando as mensagens subentendidas: "Quando a gente tá fazendo a leitura de um texto, qualquer texto, é muito importante a gente ler para além das palavras, do que que a palavra tá escrita, no concreto, mas o que que é, qual é o sentido daquela palavra, qual é o sentido daquela frase. Quando a gente passa a tomar cuidado com a leitura é, pra gente perceber o que está nas entrelinhas, ou o que que tá sendo dito, também, naquelas palavras, a gente acaba, aprendendo, acaba aprendendo melhor, compreendendo mais facilmente o sentido das coisas, tá bom?"

Esse exercício que o professor fez com os alunos nesses dois momentos configura-se como um exercício fundamental do modo de pensar histórico. Mark Bloch $(2001)^{7}$, um dos fundadores da escola dos Annales, ao discorrer sobre a relação dos historiadores com os testemunhos do passado argumenta que o historiador apega-se muito mais e "com muito mais ardor" ao que os textos nos deixam a entender, sem haver pretendido dizê-lo. Quando interrogamos "textos históricos", neste caso uma fonte histórica da antiguidade, interrogamos sobre as maneiras de ou de pensar particulares as épocas em que foram feitas. (Essas mensagens estão, muitas vezes, subentendidas na materialidade do texto).

\footnotetext{
7 O historiador Mark Bloch escreveu sua obra Apologia da História ou Ofício do historiador na prisão na França, antes de ser fuzilado pelos nazistas durante a Segunda Guerra Mundial. Ela possui várias edições, sendo que a que utilizamos aqui é a última delas, publicada recentemente por seu filho.
} 
Questionamos também, ainda na perspectiva do historiador francês, sobre todas as coisas que os antepassados não tinham intenção de expor, conseguindo, assim, saber sobre o passado "muito mais do que ele julgara sensato nos dar a conhecer". Desse modo, com respostas próprias, o professor parece realizar com os alunos movimentos semelhantes ao que sugeriu o historiador Marc Block. Parece que, de forma particular, o prof. Odilon está incentivando os alunos a fazerem um movimento de análise dos "textos" históricos, dos "testemunhos da História", de modo a apreender as mensagens subentendidas, como meio para compreender "mais facilmente o sentido das coisas".

Assim, nesses dois momentos, a natureza da leitura dos textos de História que o professor arquitetou com os alunos foi de teor mais crítico, para além da superfície do texto, que foge a sua literalidade. Ademais, nessas linhas, o professor reflete sobre a ação de ler o texto histórico nas entrelinhas, como um ato potencial que deve informar as futuras leituras do grupo. Ler os não ditos do texto foi, desse modo, uma das formas de ler História construídas nesse ciclo.

Retomando o fluxo discursivo do subevento em análise, após fazer um intertexto com o evento anterior, reeditando o modo como os alunos deveriam ler um texto de História, nas entrelinhas, o professor repetiu a pergunta. A pergunta foi reformulada, para que os alunos entrassem em outra chave de interpretação, na qual a noção de mãe seria mobilizada para auxiliar na constatação de imagens sobre a deusa-mãe: "Gente!!!/ O que que torna uma mulher mãe?/" Sua fala é interrompida pela sugestão do aluno Felipe, que aponta a amamentação como característica de uma mãe: "Acho que ela pode amamentar os filhos/". O professor elogia o comentário do aluno, dizendo ter suprido suas expectativas: "Isso!/ Felipe/ era isso que eu queria ouvir!/". Os demais alunos aclamam Felipe por meio de palmas e gritos.

Visando garantir que a turma compreendesse a hipótese proferida por Felipe, o professor repetiu a pergunta sobre as características de uma mãe: "O que que torna uma mulher.../ gente!!!/ O que que torna uma mulher mãe?/". Para respondê-la o aluno Willian relacionou as características de uma mãe à capacidade de fazer sexo: "fazer sexo/". A participação de Willian gerou um contexto de risos, conversas e brincadeiras. O professor aguardou a desordem da turma para, então, rebater a afirmação de Willian. Para tanto, ele levantou a possibilidade de o ato 
sexual não estar voltado para a maternidade. Depois disso, há vários turnos de fala em que os alunos continuam rindo e conversando e o professor chamando a atenção da turma. Falar sobre sexo desperta o interesse dos alunos dessa faixa etária, por isso os risos, conversas e a dificuldade do professor de conduzir a aula. Mediados por suas experiências culturais, os alunos interpretam a questão do professor focando nas relações entre homem-mulher (sexo) e não consideram, assim, as relações entre mãe e filho.

Ao conseguir novamente a atenção dos alunos, fazendo com que estes estivessem orientados para o que propunha para a turma e não estivessem dispersos em conversas paralelas, o professor definiu o modo como os alunos deveriam participar da discussão: "Eu tô precisando que vocês falem um pouco mais sem medo!/ Porque eu tô perguntando as coisas/ e todo mundo fica querendo dar uma resposta muito difícil/ e complicada./". Ele critica as explicações elaboradas, complicadas, ressaltando que as características mais diretas das relações entre mães e filhos estão sendo negligenciadas.

Redirecionando o fluxo a partir desse comentário, o professor fez uma pergunta sobre o que tornaria uma mulher mãe, respondendo-a ele próprio: "ter filhos". Então, ele reforça essa assertiva por meio da repetição: "Quer dizer simples!/ Ter um filho/ torna uma mulher mãe/". Em seguida, usou a voz do aluno Felipe para elaborar sua explicação sobre uma das características de uma boa mãe, ou seja, a amamentação: "E aí o Felipe matou a charada/ porque quando se pensa numa mãe/ e para uma mãe ser boa/ né?/ Ser uma boa mãe/ ela tem que/ no primeiro momento/ ela tem que fazer o quê?/ Amamentar seus filhos/ Não é?/ Alimentar/ senão ele não vai .../ sobreviver/ Não é?/". Novamente, os alunos foram definidos como interlocutores do conhecimento que estava sendo produzido na interação e co-construtores do "texto" coletivo da sala de aula.

Dando continuidade a seu raciocínio, o professor reformulou a pergunta sobre a representação da deusa-mãe, incluindo o homem da antiguidade e suas intenções e preocupações ao representá-la: "Então.../Quando o homem láaaa/ na Antiguidade/ quis representar a deusa-mãe/ qual foi a preocupação/ dele/ em retratá-la?/ O que que ele pensou em agregar à imagem dessa deusa-mãe/ para ela simbolizar/ só da gente bate olho/ e saber que ela era uma deusa/ a deusamãe/" Com isso, ele trouxe para a cena pedagógica o sujeito histórico com suas 
intenções, ideias e motivações. O professor introduziu o objeto como integrante de uma organização social, de uma parte da vida cotidiana, dos rituais, da arte de determinado grupo social. Os estudantes foram motivados, então, a buscar os sentidos que nortearam a vida de atores sociais de uma determinada época, a civilização indiana em seus primeiros tempos. Eles foram levados a construir possíveis explicações sobre as motivações do autor da imagem, da representação e as ideias que sustentavam essa representação.

Ruan respondeu à pergunta do professor de forma literal repetindo as características da deusa-mãe: seios grandes e quadris largos. O professor pediu os motivos, os significados de tal representação. A aluna Paiva, que havia solicitado espaço para falar, foi convocada pelo professor para debater sobre o tema. Paiva apresentou, em sua fala, os supostos motivos da representação: quadris largos porque ela estava grávida e seios grandes porque ela ia amamentar. O professor expressou um "tá", que pareceu ser uma pista contextual de que estava satisfeito com a síntese elaborada pela aluna, pois logo em seguida construiu um contexto de mudança de foco, conformando a terceira sequência interacional "Imaginando a estatueta da deusa-mãe" que segue abaixo. 


\begin{tabular}{|c|c|c|}
\hline $\mathbf{P}$ & Discurso & Aspectos Culturais \\
\hline$P$ & $\begin{array}{l}\text { tá/ agora vem a pergunta/ [segurando a } \\
\text { revista] Todos vocês aqui/ já conseguiram } \\
\text { imaginar a estátua/ da deusa-mãe?/ }\end{array}$ & $\begin{array}{l}\text { Encorajando os } \\
\text { alunos a imaginar a } \\
\text { estátua da deusa- } \\
\text { mãe. }\end{array}$ \\
\hline $\mathrm{Ru}$ & $\begin{array}{l}\text { Eu já!/ Eu já!/ [alunos falam ao mesmo } \\
\text { tempo] Deixa eu/ }\end{array}$ & $\begin{array}{l}\text { Solicitando } \\
\text { participação }\end{array}$ \\
\hline$P$ & $\begin{array}{l}\text { Eu deixo!/ Calma/ Ruan!/ Ruan/ Ruan!/ Eu } \\
\text { tô deixando todo mundo/ calma!/ Ruan/ eu } \\
\text { tô pedindo para as pessoas imaginarem/ } \\
\text { então não tem ordem!/ 'Sou eu primeiro'/ eu } \\
\text { tô pedindo pra imaginar!/ }\end{array}$ & $\begin{array}{l}\text { Definindo o espaço } \\
\text { como coletivo. } \\
\text { Esclarecendo para } \\
\text { Ruan que não é o } \\
\text { momento de falar, e } \\
\text { sim de imaginar. }\end{array}$ \\
\hline$P$ & $\begin{array}{l}\text { Pera aí/ [levantando-se de sua mesa, } \\
\text { segurando a revista] Queria que vocês } \\
\text { imaginassem a deusa- mãe/ Pera aí/ Pera } \\
\text { aí!/Tá/ Brenda/ Pera aí/ Pera aí/ tô } \\
\text { pedindo.../ o exercício por enquanto é pra } \\
\text { imaginar a .../ por favor/ gente!/ O que eu tô } \\
\text { pedindo/ o exercício aqui é pra imaginar/ a } \\
\text { deusa/ mãe/ } \\
\text { A gente já tem duas informações/ que ela } \\
\text { tem os seios grandes/ e os quadris largos/ E } \\
\text { a } \\
\text { Paiva já explicou direitinho/ porque que ela } \\
\text { tem essa imagem/ essa representação. }\end{array}$ & 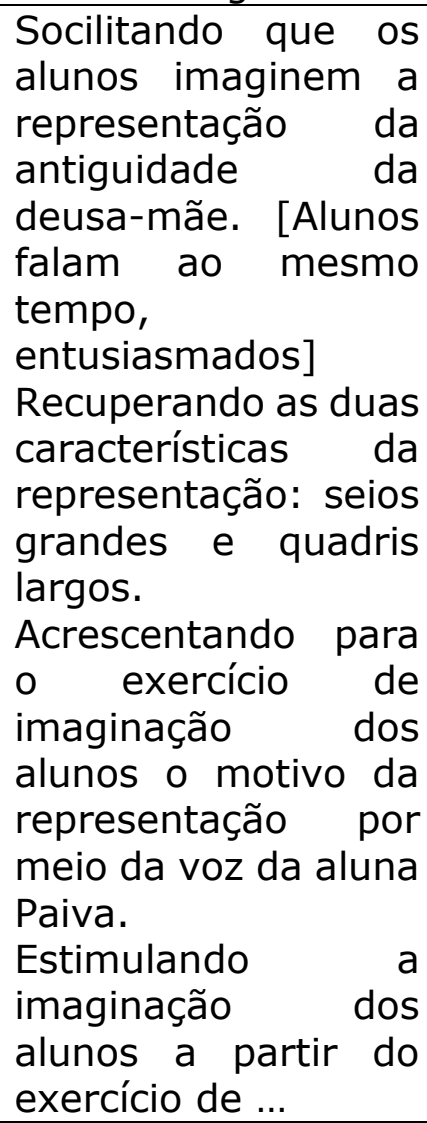 \\
\hline Als & $\begin{array}{l}\text { [Alunos fecham os livros] } \\
\text { [Alguns instantes em silêncio] } \\
\text { [em alguns instantes começam a falar de } \\
\text { novo] }\end{array}$ & \\
\hline $\mathrm{P}$ & Conseguiram?/ & \\
\hline Als & Conseguimos & \\
\hline $\mathrm{P}$ & $\begin{array}{l}\text { Será que essa imagem/ que vocês } \\
\text { imaginaram/ se parece com essa aqui?/ } \\
\text { [mostra imagem da revista] }\end{array}$ & $\begin{array}{lr}\text { Contrastando } & a \\
\text { imagem dos alunos } \\
\text { com a } \\
\text { imagem/objeto da } \\
\text { antiguidade Indiana. }\end{array}$ \\
\hline
\end{tabular}




\begin{tabular}{|c|c|c|}
\hline & & $\begin{array}{l}\text { (Colocando duas } \\
\text { imagens e dois } \\
\text { mundos em diálogo) }\end{array}$ \\
\hline Als & alunos gritam e começam a rir, a gargalhar & $\begin{array}{l}\text { Mostrando que } \\
\text { seguem a narrativa } \\
\text { da aula. }\end{array}$ \\
\hline$P$ & [espera um tempo o barulho] & \\
\hline$P$ & $\begin{array}{l}\text { Olha aqui/ pshhhhh!/ [Depois de um tempo, } \\
\text { bate a chave na mesa (para chamar } \\
\text { atenção)] Olha só!/ Vamos lá/ vamos lá!/ } \\
\text { Pshhh!/ Ruan/ agora chega/ Pshhh/ } \\
\text { [continua batendo com a chave] Gente!/ } \\
\text { Willian!/ Willian/ pshhhh!/ Por favor/ gente/ } \\
\text { Bom/ oooi.../ Lorena/ Olha só/ gente/ } \\
\text { Ruan!/Espera aí/ gente!/ Sem exagero!/ } \\
\text { Ruan!/ Sem exagero!/ [Vai a carteira de } \\
\text { Ruan] Vai lá ao banheiro/ e recupera sua.../ } \\
\text { pode ir ao banheiro!/Ruan!/ Ruan/ Pshh/ } \\
\text { [para Lorena] ooooou/ tá bom!/ Tô } \\
\text { entendendo que você tá achando muita } \\
\text { graça/ já tá claro pra todo mundo/ beleza?/ } \\
\text { Tá/ olha só/ Pshhhh!/ Natali!/ } \\
\text { Naatali!!/Gente/ agora chega/ tem limite pra } \\
\text { tudo/ espera aí/ Pshhh... / }\end{array}$ & $\begin{array}{l}\text { Chamando a atenção } \\
\text { da turma. }\end{array}$ \\
\hline$P$ & $\begin{array}{l}\text { Olha só/ na Antiguidade/ na tentativa de } \\
\text { representar/ a fertilidade/ né/ o que que é } \\
\text { fertilidade/ é uma mulher que tem muitos } \\
\text { filhos/ e aí quando a mulher tem muitos } \\
\text { filhos/ né/ os quadris ficam mais largos/ } \\
\text { então a deusa mãe.../ }\end{array}$ & $\begin{array}{lr}\text { [Alunos vão } & \text { se } \\
\text { acalmando] } & \\
\text { Explicando } & \text { as } \\
\text { intenções } & \text { e } \\
\text { preocupações } & \text { do } \\
\text { autor da imagem. }\end{array}$ \\
\hline $\mathrm{Al}$ & Já perdeu a graça. & $\begin{array}{l}\text { [alunos comentam, } \\
\text { continuam rindo da } \\
\text { imagem] }\end{array}$ \\
\hline$P$ & $\begin{array}{l}\text { Eu também acho/ já perdeu a graça mas tem } \\
\text { gente insistindo/ } \\
\text { [Para Lorena] Você está me obrigando a ser/ } \\
\text { quem eu não gosto de ser/ Você entendeu o } \\
\text { que eu disse?/ Você está me obrigando a ser } \\
\text { quem eu não gosto de ser/ }\end{array}$ & $\begin{array}{l}\text { Chamando a atenção } \\
\text { da turma. } \\
\text { Chamando a atenção } \\
\text { da Lorena. } \\
\text { Colocando a } \\
\text { reponsabilidade de } \\
\text { agir de forma } \\
\text { diferente nos alunos }\end{array}$ \\
\hline$P$ & $\begin{array}{l}\text { Então/ o autor/ né/ o artista/ que fez essa } \\
\text { obra/ essa estatueta/ ele tinha a } \\
\text { preocupação de representar a fertilidade/ } \\
\text { da mulher que tem vários filhos/ ela é a } \\
\text { deusa-mãe/ ela é a mãe de todos/ né?/ A } \\
\text { preocupação em assegurar a sobrevivência } \\
\text { dos seus filhos/ com seios fartos/ [aponta }\end{array}$ & $\begin{array}{ll}\text { Seguindo } & a \\
\text { explicação }\end{array}$ \\
\hline
\end{tabular}




\begin{tabular}{|c|c|c|}
\hline & $\begin{array}{l}\text { para os seios da estátua]/ } \\
\text { consequentemente/ com bastante leite/ pra } \\
\text { não deixar.../ pra não deixar que nenhum } \\
\text { dos seus filhos/ morra de fome/ Tá?/ E ele } \\
\text { não se preocupou/ em dar um rosto à } \\
\text { imagem/ percebem?/ [apontando para a } \\
\text { cabeça da imagem] }\end{array}$ & $\begin{array}{lr}\text { Ressaltando } & \text { uma } \\
\text { característica } & \text { da } \\
\text { imagem. } & \end{array}$ \\
\hline$P$ & $\begin{array}{l}\text { Eu vou deixar a revista aqui/ pra passar de } \\
\text { mesa em mesa. }\end{array}$ & $\begin{array}{l}\text { Permitindo o contato } \\
\text { dos alunos com a } \\
\text { fonte histórica. }\end{array}$ \\
\hline Mau & Ah não/ veio/ para/ & $\begin{array}{lr}\text { Reforçando uma } \\
\text { atitude de } \\
\text { estranhamento } \\
\text { diante da imagem } \\
\text { quando pensa na } \\
\text { possibilidade } \\
\text { novo contato com } \\
\text { ela. }\end{array}$ \\
\hline$P$ & $\begin{array}{l}\text { Mauro/ se você acha que não tem } \\
\text { maturidade pra ver a foto/ quando chegar a } \\
\text { sua vez/ você passa pra outra pessoa/ tá } \\
\text { bom?/ } \\
\text { [Deixa a revista com a aluna na primeira } \\
\text { fileira] }\end{array}$ & $\begin{array}{lr}\text { Trabalhando } & \text { o } \\
\text { controle da turma } \\
\text { para não } \\
\text { desencadear em } \\
\text { nova euforia coletiva } \\
\text { por meio de uma } \\
\text { crítica pública a uma } \\
\text { atitude do aluno } \\
\text { Mauro considerada } \\
\text { infantil. }\end{array}$ \\
\hline$P$ & [Volta e assenta na sua mesa] & $\begin{array}{l}\text { Mudando o espaço } \\
\text { interacional } \\
\text { Pista contextual de } \\
\text { que quer mudar de } \\
\text { assunto. }\end{array}$ \\
\hline$P$ & $\begin{array}{l}\text { Ô/ Natali/ você tinha pedido pra.../ } \\
\text { Não/ não/ é.../ Laís/ }\end{array}$ & Convocando leitor. \\
\hline Ste & Ela já leu/ fessor/. & \\
\hline $\mathrm{P}$ & Termina só esse trechinho pra mim/ Laís/ & $\begin{array}{l}\text { Indicando parte a ser } \\
\text { lida. } \\
\text { (sinalizando início de } \\
\text { nova sequência) }\end{array}$ \\
\hline
\end{tabular}

Tabela 3: Representação da transcrição da sequência "Imaginando a estatueta da deusa-mãe" do subevento "Discutindo a representação da deusa-mãe" Aula de 10/09/2010

De acordo com a transcrição acima, alternando a atividade, o professor encorajou os alunos a imaginarem a estátua da deusa-mãe. Ruan solicitou a fala dizendo "Eu já, eu já". O professor alegou que o espaço era coletivo e que todos podiam falar - "Eu deixo!/ Calma/ Ruan!/ Ruan/ Ruan!/ Eu tô deixando todo 
mundo/ calma!/" - e, em seguida, esclareceu para o aluno que não era o momento de falar, e sim de imaginar "Ruan/ eu tô pedindo para as pessoas imaginarem/ então não tem ordem!/ 'Sou eu primeiro'/ eu tô pedindo pra imaginar!/". Para isso, ele alternou o espaço interacional: levanta-se de sua mesa portando a revista e, de pé, de frente para a turma, pediu para que os alunos fizessem um esforço de imaginação. Com isso, ele deu continuidade ao diálogo entre os alunos e a fonte histórica da antiguidade. Para povoar a imaginação dos alunos, o professor recuperou as duas características da representação: "A gente já tem duas informações/ que ela tem os seios grandes/ e os quadris largos/"; e acrescentou o motivo da representação por meio da voz da aluna Paiva "E a Paiva já explicou direitinho/ porque que ela tem essa imagem/ essa representação". Novamente, aos alunos foi conferido o papel de interlocutores, co-construtores do "texto coletivo" da sala de aula.

Enquanto o professor realizava tais ações, foi interrompido pelo aluno Ruan que recebeu repressão de um dos seus colegas "ô Ruan!!!". Esse gesto do colega explicitou o seu interesse e engajamento na narrativa da aula.

Dando continuidade à nova atividade, o professor estimulou a imaginação dos alunos a partir do exercício de fechar os olhos. Na execução desta tarefa, ele obteve alguns instantes de silêncio da turma. Quando os alunos voltaram a conversar, o professor verificou se eles haviam executado a atividade imaginativa proposta. A partir da resposta afirmativa, ele expôs a imagem da revista para a turma. 


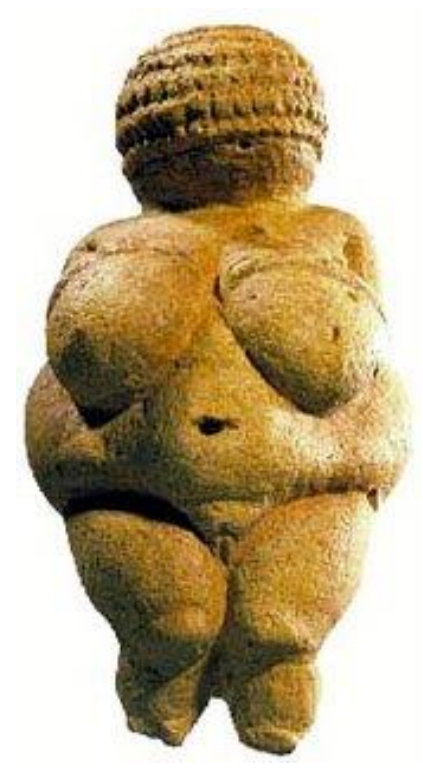

Figura 1: Imagem da estatueta da deusa-mãe da revista "Super Interessante" que foi exibida para os alunos

Com isso, o professor contrastou a imagem que povoou o imaginário dos alunos construída a partir do exercício de leitura de referências escritas com a imagem/objeto da antiguidade indiana. Ele colocou duas imagens/representações em choque. Se na antiguidade (indiana) o contexto de visualização de imagens como esta apontava para um uso afetivo e de autoridade e poder da imagem, geralmente atrelada a rituais religiosos (BEZERRA DE MENEZES, 2003), como a própria narrativa do livro didático indicou, o contexto de uma sala de aula de História brasileira de ensino fundamental imprimiu um uso cognitivo da imagem bastante distinto. Em contato com a fonte histórica, a reação dos alunos foi de euforia coletiva: muitos risos, comentários, conversas, gargalhadas durante muito tempo. A forma como os alunos reagiram demonstra que eles acompanhavam a narrativa da aula e, portanto, fizeram os exercícios de dialogar com a representação da deusa-mãe (de pensar sobre o passado a partir dela), de discutir suas metáforas e entrelinhas bem como de imaginar suas características físicas. 0 professor deixou que os alunos expressassem livremente suas impressões fazendo um exercício de sensibilidade estética. Coube a ele, em decorrência, dispensar um tempo considerável na tentativa de controlar essa euforia produzida pelo diálogo entre as duas representações. Parece que essa atividade estimulada pelo professor deu origem a um profundo estranhamento entre as percepções de mundo dos alunos e a percepção de mundo dos homens da antiguidade. A atividade permitiu 
um exercício próprio do pensar histórico de deslocar-se no tempo e reconhecer o "outro", o "diferente". O contato com uma manifestação cultural distinta fez com que os alunos se deslocassem para um tempo histórico distinto, impregnado por outros valores culturais e estéticos e voltassem novamente para o presente refletindo sobre seus próprios valores, reconhecendo-se no mundo e na própria cultura. Os risos, gargalhadas, a euforia coletiva nos deram a saber que os alunos eram partícipes de outro meio cultural que não reconhecia os valores presentes na materialidade da imagem que, por sua vez, revelavam traços da cultura de uma dada sociedade distante da dos alunos. As chaves de leitura de que os alunos dispunham fizeram com que eles se reconhecessem como integrantes de um mundo com valores estéticos diferentes daqueles do objeto histórico oriundo de outra manifestação cultural. Com isso, eles puderam refletir sobre os próprios valores.

Argumentamos, mais uma vez com Wilhelm Dilthey em $A$ construção do mundo histórico nas ciências humanas (2010), que o mundo histórico é vivencial. O estudante, ao mesmo tempo em que ele se aproxima da interpretação histórica, está no mundo histórico partilhando experiências, vivendo situações similares. $O$ choque e o estranhamento dos alunos em contato com a fonte histórica da antiguidade fizeram dialogar sujeitos em temporalidades históricas diferentes. Para interpretar a fonte histórica, os alunos, como seres históricos, olharam para ela carregados de valores de seu universo cultural. A leitura deles foi mediada pelos valores do mundo histórico a que pertencem. Outra vez, cabe recuperar a fala do historiador quando afirma que: "O mundo histórico está sempre presente e o indivíduo não o considera apenas de fora, mas está entretecido nele. (...) Antes de nos tornarmos observadores da história, somos seres históricos e é somente porque somos seres históricos que nos tornamos tais observadores" (Dilthey, 2010).

A narrativa histórica criada nas interações, desse modo, colocou os alunos diante de "textos"/imagens de outra temporalidade. Esse contato provocou neles um estranhamento que permitiu a tomada de consciência de seus próprios valores culturais, num trabalho de reconhecimento de si no mundo. Essa atividade contribuiu para que os alunos fizessem movimentos de pensar historicamente, pois 
puderam contrastar temporalidades históricas e fazer um exercício de alteridade em que identificaram valores culturais, estéticos e sociais distintos dos próprios, percebendo-se como partícipes de outro universo cultural.

Após alguns minutos tentando controlar a euforia coletiva causada pelo choque entre os dois mundos, o professor fez um ensaio para explicar as intenções e preocupações do criador da imagem. Segundo o professor, o autor tinha a preocupação de representar a fertilidade da mulher e, por isso, a retratou com seios fartos, para "assegurar a sobrevivência dos seus filhos", e quadris largos, "quando a mulher tem muitos filhos/ né/ os quadris ficam mais largos/ então a deusa-mãe...". O professor tecia essa explicação ao mesmo tempo em que apontava para as características da imagem. Fez isso alternando alguns instantes de gestão de classe em que chamava a atenção da turma, principalmente da aluna Lorena quando colocou nela a responsabilidade por ele estar tendo uma atitude mais ríspida: "Você está me obrigando a ser/ quem eu não gosto de ser/ Você entendeu o que eu disse?/ Você está me obrigando a ser quem eu não gosto de ser/".

A seguir, o professor propôs novo contato dos alunos com a fonte histórica, pedindo que a revista fosse repassada pelas carteiras dos alunos para que, individualmente, eles tivessem a oportunidade de contemplar a imagem. A reação de um deles, Mauro, quando brincou "Ah não, veio, para"/ recuperou a atitude de estranhamento diante da imagem (que levou aos risos e à euforia) quando pensou na possibilidade de novo contato com a representação, tida como engraçada. Em reação, o professor, por meio de uma crítica pública à atitude desse aluno, trabalhou o controle da turma para não desencadear novamente uma euforia coletiva: "Mauro/ se você acha que não tem maturidade pra ver a foto/ quando chegar a sua vez/ você passa pra outra pessoa/ tá bom?/".

Após deixar a revista com a aluna da primeira carteira da direita, o professor retornou a seus assentos, alternando novamente o espaço interacional. Com isso, ele deixou uma pista contextual de que iria alternar a atividade. A seguir, convocou um aluno para prosseguir na leitura, dando origem a novo subevento.

No entanto, a leitura seguiu ao mesmo tempo em que a revista com a estatueta da antiguidade percorria as carteiras. A presença da representação se 
fez sentir no desenrolar da aula, conforme mostra a transcrição a seguir que conformou o subevento "Discutindo as características da estatueta da deusa-mãe".

\section{Qual História foi aprendida nos atos de ler}

Os significados construídos nessa atividade tiveram consequências a longo prazo. Nas entrevistas com os alunos, no final do ano letivo, as lembranças dessa aula ainda povoavam suas memórias: "(...) teve até uma vez que ele tava explicando uma matéria sobre os deuses, tava lá na revista, tava o nome do deus, do deus e tudo que éé... a vida dele toda, como que ele virou deus, por que que ele era deus" (Geisson); "(...) ele pegou uma revista e leu umas histórias pra gente. Leu sobre história lá, sobre a deusa-mãe, sei que foi a maior confusão por causa disso. Por causa da deusa-mãe, aí todo mundo começou a rir, a fazer piadinha, aí atrapalhou a aula inteira, ficou quase metade da aula fazendo isso" (Stefany). "Esses dias, é, acho que foi mês passado, ele trouxe uma revista ótima, é, de, é... uma revista que falava da antiguidade, falava dos povos indígenas, falava de uma gueixa lá indiana, falava de umas cartas assim, de uma mulher gorda, assim. Muito, aí, é... essa aula foi muito interessante, todo mundo participou, aí ele deu a revista, até a figura era muito engraçada, aí todo mundo foi passando assim olhando a revista, foi muito engraçado" (Paiva). Com nuances de nitidez, as memórias dos alunos mostram marcas dessa atividade para suas aprendizagens revelando saberes construídos sobre História particulares desse grupo durante o ano letivo.

Nos subeventos analisados acima, elementos específicos da forma de pensar historicamente foram produzidos na interação, informando modos de ler e aprender História construídos na prática de leitura debatida do texto de História dessa sala de aula. Nas interações, o professor construiu modos particulares de ler os textos nas entrelinhas, buscando as mensagens subentendidas, bem como definiu conceitos de várias ordens visando ao entendimento dos textos pelos alunos. Ademais, os estudantes tiveram oportunidades de dialogar com fontes históricas. Nesses diálogos, os aprendizes fizeram exercícios de alteridade entre dois mundos históricos: o mundo da antiguidade indiana onde a fonte foi produzida 
e o mundo histórico deles mesmos. Nessa jornada, ao estranhar a fonte histórica, os alunos deslocaram-se no tempo, percebendo realidades históricas distintas. Com isso, eles ganharam consciência de seus próprios valores culturais e estéticos, reconhecendo-se como partícipes do presente em que vivem. A prática de leitura do texto histórico construída socialmente pelo professor e pelos alunos, desse modo, conformou modos específicos de ler e aprender Histórica co-construídos por professor e alunos. O diagrama abaixo resume esses aspectos do pensar historicamente que despontaram nas interações.

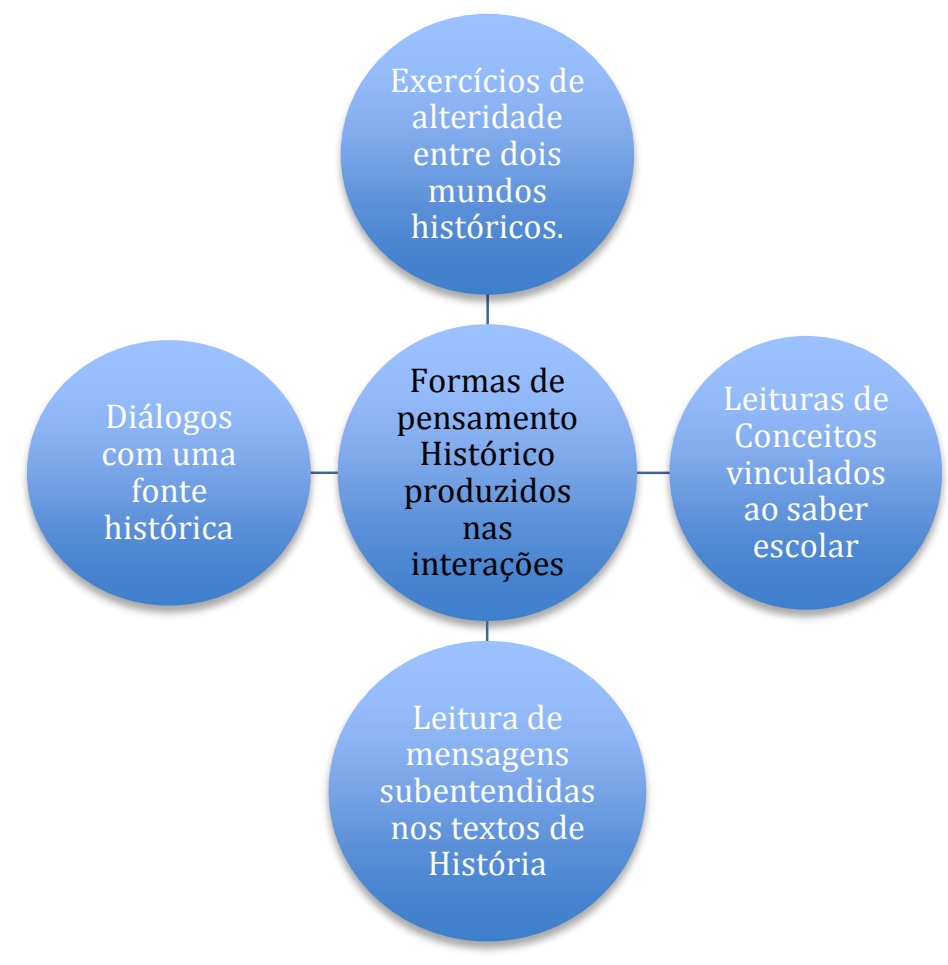

\section{Diagrama 1: Aspectos do pensar historicamente que despontaram nas interações do segundo ciclo}

Na prática analisada os alunos foram levados a refletir sobre suas ações e sobre os raciocínios construídos no movimento dialógico produzido em sala de aula. O professor construiu com os alunos reflexões e raciocínios sobre o que significa ler as entrelinhas, os não ditos, as mensagens subentendidas dos textos; sobre como argumentar e preencher lacunas dos textos de História do livro didático; sobre como participar da dinâmica de leitura. A análise desse subevento demonstrou o caráter reflexivo do discurso e da prática desse professor sendo, 
assim, constituinte e constituidor das práticas de leitura dos textos de História desse grupo social.

A prática de leitura debatida emergiu como forma de enfatizar ainda mais as habilidades de leituras do texto histórico dos alunos, dando destaque à leitura das metáforas e entrelinhas do texto, ao entendimento de conceitos, palavras e expressões do texto. Alunos e professor co-construíram modos particulares e um conhecimento cultural compartilhado de como participar da leitura do texto de História em que ler, discutir e comentar é direito e papel de todos. Quanto às narrativas históricas construídas, o contexto dos subeventos analisados produziu outros modos de pensar historicamente, como o trabalho com a fonte histórica e o exercício de estranhamento entre dois mundos históricos.

Cabe acrescentar ainda que ao analisar, momento por momento, o processo de construção das práticas de leitura dos textos históricos do livro didático (sobretudo), revelamos como o professor construiu uma cultura de leitura dos textos de História local e particular. No descortinar desse processo percebemos que o professor instituiu com os alunos uma prática reflexiva e não homogênea de uso do livro didático. Nessa prática não predominou a "ortodoxia" dos textos do livro didático, uma vez que várias vozes do saber histórico tiveram, nas interações, autonomia como enunciadoras da História, entre elas, a voz dos alunos, do professor e dos outros textos utilizados (a revista de divulgação científica, os filmes, os intertextos). O livro didático, embora usado na maioria das aulas, se configurou, portanto, como mais uma voz do conhecimento histórico entre as outras presentes. Foi possível perceber que o professor e os alunos contrariaram, acrescentaram, extrapolaram, ampliaram, questionaram e tomaram apenas como ponto de partida as narrativas históricas do livro didático. A interação oral, portanto, configurou uma prática de leitura dos textos de História plural e dialógica frente ao saber histórico.

Essa análise permitiu-nos compreender a prática de leitura dos textos de História em uma sala de aula de História que conformou modos específicos de ser aluno, de ser professor, e de agir, participar, saber, ler e aprender História.

professor criou, co-construiu com os alunos um ambiente de leitura de uma fonte histórica em que os estudantes, engajados na narrativa, manifestaram suas 
percepções de mundo, deslocaram-se no tempo, recriaram seus valores estéticos e culturais, e, por conseguinte, aprenderam História.

\section{Referências}

AISENBERG, B. Una aproximación a la relación entre la lectura y el aprendizaje de la Historia. Revista Íber n. 43. Didáctica de Ciencias Sociales, Geografía, Historia. Barcelona: Editorial Grao, p. 94-104. 2005

ANDRADE, L. T.; GREEN, J.; CASTANHEIRA, M. L. Becoming an ethnographer: exploring the power of different epistemological approaches to analysing literacy events in a History Class in Brazil In: Ethnography and Education Conference, University of Oxford, England. 2012.

ANDRADE, L. T. Praticas de Leitura em aulas de História: um estudo de caso etnográfico. Belo Horizonte: UFMG MG (Dissertação, Mestrado em Educação). 2006.

BLOCH, M. Apologia da história ou o ofício de historiador. Rio de Janeiro: Jorge Zahar. 2002.

BLOOME, D.; EGAN-ROBERTSON, A. (1993). The social construction of intertextuality in classroom reading and writing lessons. Reading Research Quarterly. v. 4., n. 28, p. 305-333. 1993.

BLOOME, D.; BAILEY, F. A special issue on intertextuality. Linguistic and Education. v.4. 1992.

BRAICK; MOTA. História: das cavernas ao terceiro milênio, Editora Moderna. 2006.

CARIE, N. S. de. Usos dos livros didáticos em sala de aula: a ortodoxia do professor. Monografia apresentada ao Curso de História da Universidade Federal de Minas Gerais. Belo Horizonte. 2004.

CASTANHEIRA, M. L. Aprendizagem Contextualizada: discurso e inclusão na sala de aula. Belo Horizonte: Autêntica, v. 1. 2004.

CHOPAIN, F. A. História dos livros didáticos e das edições didáticas: sobre o estado da arte. Rev. Educação e Pesquisa, São Paulo, v. 30, n. 3, p. 549-566, set./dez. 2004.

COELHO, A.; SIMAN, L. M. de C. O papel da ação mediada na construção de conceitos históricos. Anais do II Encontro Internacional Linguagem, Cultura e Cognição: reflexões para o ensino - CD-ROM-, Campinas: Graf. FE. 2003. 
COLLINS, E.; GREEN, J. Learning in Classroom Settings: making or breaking a culture. In MARSHALL, H. (Ed.). Redefining Students Learning, p. 59-85. 1994.

DILTHEY, W. A construção do mundo histórico nas ciências humanas São Paulo, UNESP. 2010.

ESPÍNDOLA, D. P. A. O uso do livro didático em sala de aula: possibilidades para a prática do ensino de história. Dissertação, Mestrado em Educação), Faculdade de Educação da Universidade Federal de Minas Gerais. 2003.

FLORIANI, A. Negotiating what counts: Roles and relationships, content and meaning, texts and context. Linguistics and Education, 5 (3 \& 4). Norwood, NJ: Ablex, p. 241-274. 1993.

GEE, J.; GREEN, J. Discourse Analysis, learning, and social practice: A methodological study. Review of Research in Education. American Educational Research Association. Washington, D.C., 23, p. 119-169. 1998.

GREEN, J. L; DIXON, C. N; \& ZAHARLICK, A. Ethnography as a logic of inquiry. In FLOOD, J; LAPP, D; SQUIRE, J. R; \& JENSEN, J. M. Handbook of research on the teaching of the English language arts. 2nd ed. Lawrence Erlbaum associates, publishers, p. 201-224. 2002.

GUMPERZ, J.J. Contextualization and understanding. In DURANTI, A. \& GOODWIN, C., (eds.), Rethinking Context. Cambridge, UK: Cambridge University Press, p. 229-252. 1992.

LAUTIER, N. À la rencontre de l' histoire. Presses Universitaires du Septentrion, Paris. 1997.

MENEZES, B. de. Fontes visuais, cultura visual, História visual: balance provisorio, propostas cautelares. Revista Brasileira de História; volume 23, número 45, páginas 11-36. Julho 2003.

MONTEIRO, A. M. A história ensinada: algumas configurações do saber escolar. História \& Ensino. v. 9. p. 9-36. 2003.

PEREIRA, J. S.; CARVALHO, M. V. Sentidos dos tempos na relação museu-escola. Cadernos CEDES (Impresso), v. 30, p. 383-396. 2010.

ROCHA, H. A. B. O lugar da linguagem no ensino de história: entre a oralidade e a escrita. Tese (Doutorado em História) - Universidade Federal Fluminense. 2006.

SANTA BARBARA DISCOURSE GROUP. Constructing literacy in classrooms: Literate action as social accomplishment. In MARSHALL, H. (ed.), Redefining student learning: Roots of educational change (p. 119-150). Norwood, NJ: Ablex 1992. 
SIMAN, L. M. C; ANDRADE, L. T. Aplicando principios y prácticas culturales de lectura del libro didáctico en la clase de historia. Revista Reseñas de Enseñanza de la Historia, v. 6, p. 193-213. 2008.

SIMAN, L.M.C; ANDRADE, L.T. O livro didático lido em sala de aula de história. São Paulo: Unicamp. 2010.

VILLALTA, L. O livro didático de história no Brasil: perspectivas de abordagem. Revista Pós-História, Assis, SP, v. 9, p. 39-59. 1997.

Recebido em 10 de junho de 2015. Aprovado em 24 de agosto de 2015. 